\title{
PENGEMBANGAN MODUL MATEMATIKA BERILUSTRASI KOMIK PADA MATERI SKALA DAN PERBANDINGAN KELAS VII SMP/MTs
}

\author{
Endah Ariastutik $^{1}$, Tri Atmojo Kusmayadi ${ }^{2}$ Imam Sujadi $^{3}$ \\ ${ }^{1,2,3}$ Prodi Magister Pendidikan Matematika, FKIP Universitas Sebelas Maret Surakarta
}

\begin{abstract}
This study aims at: 1) investigating elegibility of comic-illustrated mathematics module on the materials of scale and comparison for grade VII students of SMP/MTs, 2) investigating the effectiveness of comic-illustrated mathematics module on the materials of scale and comparison for grade VII students of SMP/MTs. This study was a research and development $(\mathrm{R} \& \mathrm{D})$ in mathematics learning at SMP/MTs. The applied development model was a development model postulated by Borg and Gall modified by Sukmadinata, which consists of three stages, including: 1) preliminary research, 2) development, and 3) field testing, each of which contains several steps. The product validation process was carried out by material experts, media experts, and respondents. The effectiveness testing for the module carried out in MTs Negeri Ngawi. The data collecting instrument used was the mathematics performance test. The content validity was measured by validators. The reliability test for measuring the test instrument applied KR-20 formula and the discriminatory power used product-moment correlation formula by Karl Pearson. The balance test was carried out by using t-test. The prerequisite tests covered normality test using Lilliefors testing method and homogeneity test using Barttlet method. The experimental design for this research was randomized post-test-only control group design. On the basis of the research findings and development, the research is concluded: 1) the comic-illustrated mathematics module was feasible to be used in learning process, the comic-illustrated mathematics module is considered feasible when the evaluation result from retriever is "good", 2) the average students learning achievement in experiment class is better than that in control class, this conclusion is in accordance with the hypotheses proposed, namely learning with comic-illustrated mathematics module on the materials of scale and comparison for grade VII of SMP/MTs is more effective than direct learning without comic-illustrated mathematics module.
\end{abstract}

Keywords: Learning Module, Mathematics Comic, Scale and Comparison.

\section{PENDAHULUAN}

Pembelajaran merupakan suatu proses dimana terjadi interaksi antara guru dengan siswa sehingga pesan dapat disampaikan dengan baik. Seiring dengan perkembangan kurikulum, paradigma pembelajaran turut berkembang dari Teacher Centered Learning (TCL) menuju Student Centered Learning (SCL). Pada Kurikulum 2013 posisi guru dalam pembelajaran sebagai fasilitator. Pendekatan yang diterapkan pada proses pembelajaran menuntut siswa untuk dapat berpikir kritis dan mencari sendiri solusi dari permasalahan serta materi yang sedang dipelajari.

Penerapan proses pembelajaran yang dikehendaki Kurikulum 2013 berpusat pada siswa dan meminimalkan metode ceramah. Rasa ingin tahu dalam diri siswa perlu ditumbuhkan dan proses pembelajaran yang diterapkan harus melatih siswa untuk dapat belajar secara mandiri. Tujuan tersebut bisa tercapai salah satunya jika minat membaca siswa tinggi. Menurut Tiemensma (2009) bahwa membaca adalah komponen terpenting di abad 21 agar bisa bertahan di era global saat ini. 
Hasil wawancara dengan guru matematika dibeberapa SMP/MTs di Kabupaten Ngawi, Kurikulum 2013 menuntut guru untuk lebih kreatif dalam melaksanakan kegiatan pembelajaran. Kendala yang dialami disebabkan kurangnya bahan ajar di sekolah. Buku yang diperoleh dari Dinas Pendidikan khususnya mata pelajaran matematika memuat materi yang sangat terbatas dan masih belum cukup untuk dijadikan bahan dalam kegiatan pembelajaran. Bahan ajar yang tersedia sangat terbatas. Sumbangan dan masukan untuk bahan ajar sangat dibutuhkan agar dapat meningkatkan hasil belajar siswa.

Berdasarkan observasi yang dilakukan, sebagian besar proses pembelajaran yang diterapkan pada mata pelajaran matematika masih berpusat pada guru. Posisi siswa pada proses pembelajaran sebagai communican tanpa memberikan feedback. Oleh karena siswa hanya berperan sebagai penerima informasi, maka pemahaman siswa terbatas pada materi yang disampaikan dan kurang memahami makna dan tujuan dari materi yang dipelajari. Fasilitas dan bahan ajar masih sangat terbatas, guru hanya memanfaatkan whiteboard selama proses pembelajaran.

Hambatan lain yang dialami selama proses pembelajaran adalah kemampuan siswa yang berbeda. Kemampuan siswa yang berbeda maka proses pembelajaran sulit dilakukan secara serempak. Siswa dengan kemampuan berpikir yang relatif rendah dibandingkan dengan teman sekelasnya akan sulit mencerna materi yang disampaikan dengan metode ceramah. Dengan demikian, siswa dituntut untuk dapat mengikuti proses pembelajaran dan mempelajari materi yang belum dipahami secara mandiri.

Kesulitan lain yang dialami siswa adalah kebosanan siswa terhadap bahan ajar yang monoton, sehingga siswa kurang tertarik dalam mengkaji bahan ajar. Siswa kurang memahami alur riil dari materi yang diajarkan. Siswa mampu menyelesaikan soal tetapi mayoritas pemahaman siswa masih bersifat abstrak. Akibatnya apabila tipe soal berbeda maka siswa kesulitan dalam mengerjakannya. Dengan demikian, alur kegiatan riil perlu digambarkan secara kronologis agar siswa dapat memahami materi dan tujuan dari pembelajaran.

Matematika merupakan ilmu universal yang berguna bagi kehidupan manusia dan juga mendasari perkembangan teknologi modern, serta mempunyai peran penting dalam berbagai disiplin dan memajukan daya pikir manusia. Perkembangan pesat di bidang teknologi informasi dan komunikasi dewasa ini dilandasi oleh perkembangan matematika di bidang teori bilangan, aljabar, analisis, teori peluang, dan matematika diskrit. Senada dengan Zakaria (2010) "At present mathematics is widely used in various fields and covering a wide range of activities". Artinya, sekarang ini matematika sering digunakan di berbagai bidang dan mencakup jangkauan yang luas dari berbagai hal. 
Selain itu, berdasarkan data Ujian Nasional tahun 2013/2014 untuk siswa SMP/MTs di Kabupaten Ngawi menunjukkan bahwa nilai rerata matematika hanya 4,68. Masih rendah dibandingkan tingkat provinsi dengan nilai rerata matematika 6,38 dan nasional dengan nilai rerata 6,10. (Sumber: PAMER)

Salah satu materi yang diujikan pada Ujian Nasional adalah skala dan perbandingan, dimana materi tersebut diberikan pada siswa kelas VII SMP/MTs pada Kurikulum 2013. Berdasarkan hasil analisis daya serap materi skala dan perbandingan menunjukkan bahwa penguasaan materi tentang skala dan perbandingan oleh siswa SMP/MTs di Kabupaten Ngawi masih belum optimal. Persentase penguasaan matematika oleh siswa SMP/MTs di Kabupaten Ngawi pada materi skala dan perbandingan hasilnya masih sangat rendah yaitu $45,62 \%$. Jika persentase tersebut diurutkan dari tertinggi ke terendah, maka persentase $45,62 \%$ pada kota/kabupaten menempati urutan ke-12. Persentase penguasaan matematika pada materi skala dan perbandingan di Kabupaten Ngawi juga masih rendah jika dibandingkan dengan propinsi yang berpresentase 62,32\% dan nasional yang berpresentase 60,18\%. (Sumber: PAMER)

Berdasarkan hasil observasi kesulitan-kesulitan yang dialami oleh siswa SMP/MTs di Kabupaten Ngawi dalam menyelesaikan soal-soal yang berkaitan dengan materi skala dan perbandingan karena siswa belum menguasai materi ini dengan baik. Sebagian besar siswa hanya menghafal materi skala dan perbandingan tanpa tahu konsepnya dengan baik. Karena sebagian besar modul pembelajaran yang ada hanya berisi materi dan soal-soal yang harus dikerjakan siswa tanpa ilustrasi yang menarik. Menurut Ginting (2005: 54) minat timbul jika siswa tertarik akan sesuatu yang dibutuhkan atau yang dipelajari bermakna baginya.

Untuk mengatasi hambatan siswa dalam memahami penjelasan guru perlu adanya bahan ajar yang menarik, mudah dipahami, dan dapat dipelajari secara mandiri. Karena bahan ajar merupakan sumber dari materi pembelajaran yang diajarkan sehingga ketiadaan bahan ajar yang memadai menghambat proses pembelajaran yang berlangsung. Supaya bahan ajar dimanfaatkan dengan optimal maka bahan ajar perlu disusun sesuai kebutuhan. Yaitu, bahan ajar yang menarik untuk dipelajari siswa secara mandiri, dan dapat menumbuhkan pemahaman yang konkrit melalui ilustrasi kejadian riil dalam materi.

Bahan ajar merupakan materi pelajaran yang disusun secara lengkap dan sistematis berdasarkan prinsip-prinsip pembelajaran yang digunakan oleh guru dan siswa dalam proses pembelajaran (Sungkono, 2009: 2). Menurut Kurniawati (2013: 9-10), bahan ajar terdiri dari 2 jenis yaitu cetak dan non cetak. Bahan ajar cetak merupakan bahan ajar dalam bentuk printout seperti modul, buku teks, lembar kerja siswa, petunjuk 
belajar, dan handout. Bahan ajar non cetak merupakan bahan ajar yang bukan dalam bentuk printout sehingga diperlukan perangkat dalam pengoperasiannya seperti komputer, proyektor, LCD dan internet. Bahan ajar non cetak dapat berupa audio pembelajaran, video pembelajaran dan multimedia interaktif. Agar bahan ajar dapat dimanfaatkan secara optimal, maka bahan ajar yang dikembangkan disesuaikan dengan karakteristik sekolah yang dituju.

Dari kedua jenis bahan ajar yang telah disebutkan, maka perlu dipilih bahan ajar yang mendukung tujuan materi pembelajaran serta dapat diterapkan di sekolah. Bahan ajar non cetak memerlukan fasilitas yang mendukung seperti computer, laptop, proyektor, LCD, dan internet. Fasilitas tersebut masih belum didukung sebagian besar SMP/MTs di Kabupaten Ngawi. Dengan demikian jenis bahan ajar yang dipilih adalah bahan ajar dalam bentuk cetak. Bahan ajar cetak yang dikembangkan disesuaikan dengan kebutuhan. Bahan ajar yang dibutuhkan adalah bahan ajar yang dapat memotivasi siswa untuk belajar mandiri sehingga pembelajaran dapat berpusat kepada siswa. Kemampuan siswa yang berbeda memerlukan bahan ajar yang dapat dipelajari secara mandiri sesuai dengan kecepatan belajar masing-masing. Bahan ajar cetak didesain agar siswa dapat belajar secara mandiri adalah modul. Menurut Kurniawati (2013: 10), modul merupakan bahan ajar yang dapat dipelajari oleh siswa dengan kemampuan dan waktu yang berbeda-beda. Salah satu karakteristik modul adalah self instructional yang merupakan salah satu ciri modul yaitu dapat dipelajari secara mandiri (Depdiknas, 2008: 4).

Kesulitan siswa yang disebabkan oleh persepsi siswa yang menganggap bahwa matematika merupakan pelajaran yang sulit dapat diatasi dengan bahasa bahan ajar yang sederhana dan mudah dipahami. Untuk mengatasi kebosanan siswa terhadap bahan ajar yang monoton maka perlu dikembangkan bahan ajar yang berbeda dan menarik untuk dipelajari. Kesulitan lain disebabkan karena pemahaman siswa masih bersifat abstrak sehingga perlu diilustrasikan kejadian riil untuk menumbuhkan pemahaman yang lebih konkrit.

Pengembangan terhadap modul yang dipilih adalah pengilustrasian materi melalui komik. Pengembangan berupa pemberian ilustrasi komik berpijak pada teori kontekstual. Teori kontekstual menyatakan bahwa pembelajaran lebih bermakna apabila dikaitkan dengan kehidupan sehari-hari. Ilustrasi kejadian sehari-hari dapat berupa contoh narasi, gambar atau komik. Ilustrasi dalam bentuk narasi cenderung monoton sehingga kurang menarik dan menimbulkan kebosanan. Dalam penelitian ilustrasi yang dipilih adalah komik karena komik lebih berkesan, memberikan pemahaman yang lebih konkrit dan meningkatkan minat baca (Sadiman, 2012: 46). Apabila dibandingkan dengan gambar biasa, komik memiliki keunggulan membentuk alur cerita, alur cerita inilah yang 
kemudian memberikan pemahaman pada siswa tetang alur kejadiaan yang sedang dibahas dalam materi skala dan perbandingan. Sedangkan berdasarkan sifatnya komik pembelajaran mempunyai sifat sederhana, jelas, mudah untuk dipahami oleh siswa (Novianti dan Syaichudin, 2010). Selain itu, komik merupakan media yang potensial untuk mengembangkan ilmu pengetahuan dan kemampuan berkomunikasi pada siswa melalui alur cerita pada gambar (Tatalovic, 2009: 17).

Tujuan penelitian dan pengembangan ini adalah: 1) mengetahui kelayakan modul matematika berilustrasi komik pada materi skala dan perbandingan kelas VII SMP/MTs, 2) mengetahui efektivitas modul matematika berilustrasi komik pada materi skala dan perbandingan kelas VII SMP/MTs.

\section{METODE PENELITIAN}

Penelitian ini dilaksanakan di MTs Negeri Ngawi pada semester ganjil tahun pelajaran 2015/2016. Penelitian dilaksanakan pada bulan Mei 2015 sampai Februari 2016. Kegiatan penelitian selama sepuluh bulan tersebut meliputi penelitian pendahuluan, penyusunan proposal, seminar proposal, penyusunan produk awal, validasi ahli, revisi produk tahap I, uji coba terbatas, revisi produk tahap II, uji efektivitas produk, analisa data, penyusunan laporan penelitian, seminar hasil penelitian, penyempurnaan akhir laporan penelitian, dan penggandaan.

Penelitian ini adalah penelitian pengembangan (research and development). Model pengembangan yang digunakan dalam penelitian ini adalah model pengembangan Borg dan Gall yang sudah dimodifikasi oleh Sukmadinata (2013: 164). Terdiri dari tiga tahapan, yaitu: 1) tahap studi pendahuluan, 2) tahap pengembangan, dan 3) tahap pengujian produk. Tahapan dan langkah-langkah model pengembangan dirangkum seperti pada Gambar 1 di bawah ini.

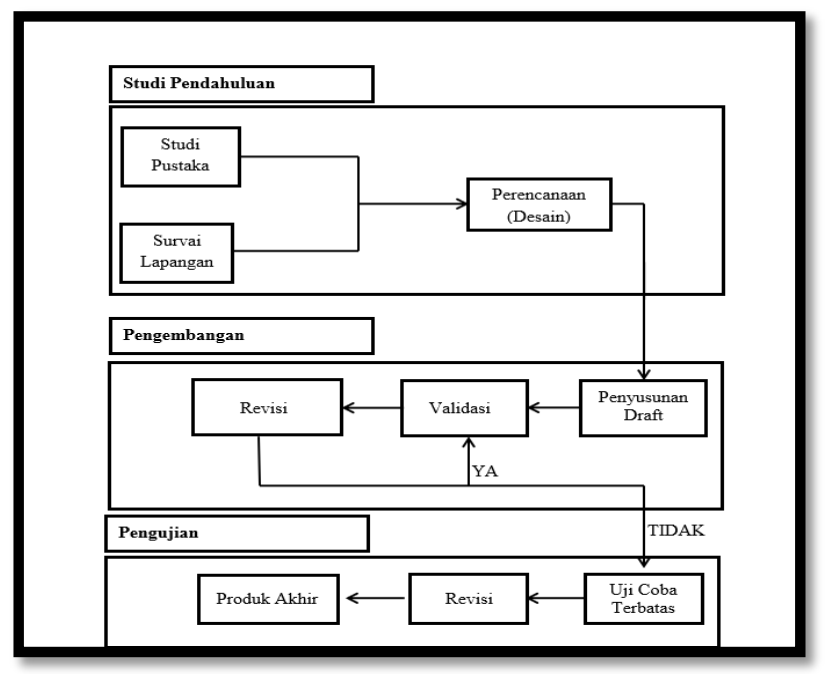

Gambar 1. Model Pengembangan Modul 
Produk yang dihasilkan berupa modul matematika berilustrasi komik. Kerangka modul yang digunakan adalah kerangka modul menurut Depdiknas (2008: 3) yang terdiri dari: 1) kata pengantar, 2) daftar isi, 3) peta konsep), 4) pendahuluan, 5) pembelajaran, 6) evaluasi, 7) kunci jawaban, dan 8) daftar pustaka. Secara lengkap kerangka modul dapat dilihat pada Gambar 2 di bawah ini.

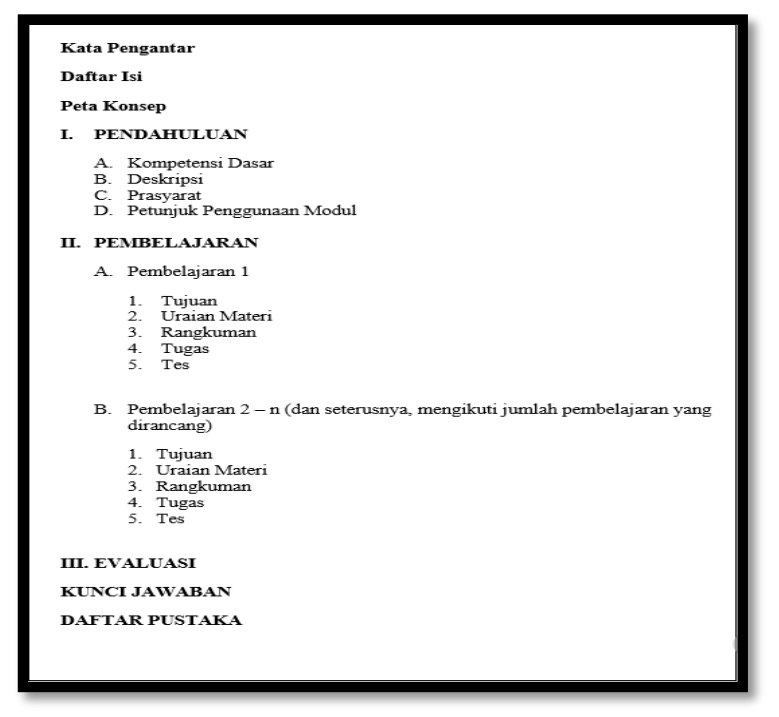

\section{Gambar 2. Kerangka Modul}

Data yang digunakan dalam penelitian ini meliputi data kualitatif dan kuantitatif. Data yang diperoleh dari hasil uji coba produk pengembangan modul pembelajaran adalah kualitatif. Data kualitatif berupa data yang diperoleh dari hasil angket dari validasi ahli materi, ahli media, dan responden. Sedangkan data yang diperoleh dari hasil uji efektivitas produk adalah kuantitatif. Data kuantitatif berupa prestasi belajar siswa.

Teknik pengumpulan data yang digunakan dalam penelitian pengembangan modul matematika berilustrasi komik ini adalah sebagai berikut: 1) wawancara, 2) angket, 3) dokumentasi, dan 4) tes. Wawancara dilakukan untuk mengetahui kondisi lapangan dan kebutuhan lapangan saat ini. Angket digunakan untuk mengumpulkan data penilaian modul oleh ahli materi, ahli media, dan responden. Dokumentasi yang digunakan dalam penelitian ini adalah dokumen yang berkaitan dengan jumlah dan daftar nama siswa yang menjadi sampel. Selain itu dokumen yang dibutuhkan adalah data kemampuan awal prestasi belajar matematika siswa yang diperoleh dari nilai Mid Semester kelas VII E dan VII F MTs Negeri Ngawi tahun pelajaran 2015/2016 dari sampel kelas eksperimen dan kelas kontrol. Data kemampuan awal digunakan untuk uji keseimbangan rata-rata. Namun, sebelum dilakukan uji keseimbangan, perlu dilakukan uji normalitas dan uji homogenitas pada masing-masing kelas.

Penyimpulan dari keberhasilan penelitian pengembangan modul matematika berilustrasi komik ini dilihat dari segi validitas secara keseluruhan. Modul matematika 
berilustrasi komik dikatakan layak apabila minimum mendapat penilaian "baik" dari reviewer. Sedangkan pada uji efektivitas modul, desain penelitian dilakukan dengan membandingkan prestasi belajar siswa pada kelas eksperimen dan kelas kontrol. Desain eksperimen yang digunakan adalah randomized posttest only control group design. Sebelum dilakukan uji hipotesis terlebih dahulu dilakukan uji prasyarat statistik parametrik meliputi uji keseimbangan, uji normalitas, dan uji homogenitas.

\section{HASIL PENELITIAN DAN PEMBAHASAN}

Model pengembangan yang digunakan dalam penelitian ini adalah model pengembangan dari Borg dan Gall yang sudah dimodifikasi oleh Sukmadinata (2013: 164). Langkah-langkah pengembangan produk dibagi menjadi tiga tahap yaitu: 1) tahap studi pendahuluan, 2) tahap pengembangan, dan 3) tahap pengujian produk dimana setiap tahapan terdiri dari beberapa langkah.

Tahap studi pendahuluan terdiri dari beberapa langkah yaitu: 1) studi pustaka, 2) survei lapangan, dan 3) perencanaan. Studi pustaka dilaksanakan di MTs Negeri Ngawi. Studi pustaka berupa analisis kurikulum, kurikulum yang digunakan kelas VII MTs Negeri Ngawi adalah kurikulum 2013. Survei lapangan dilaksanakan melalui observasi, wawancara, dan angket untuk mengetahui kebutuhan siswa dan guru serta bahan ajar yang sesuai dengan kondisi sekolah tersebut. Perencanaan meliputi pemilihan bahan ajar dan format bahan ajar. Hasil dari tahap pendahuluan adalah konsep materi dalam storyboard yang akan dikembangkan menjadi modul matematika berilustrasi komik.

Tahap pengembangan terdiri dari beberapa langkah yaitu: 1) penyusunan draf, 2) validasi, dan 3) revisi produk tahap I. Berdasarkan storyboard yang dihasilkan pada tahap sebelumnya kemudian disusun menjadi draf modul lengkap sesuai dengan kerangka modul yang disebut modul 1. Validasi terhadap modul dilakukan oleh ahli materi, ahli media, dan responden (guru matematika dan siswa). Hasil validasi berupa kelemahan dan saran dijadikan bahan evaluasi untuk revisi produk tahap I. Hasil dari tahap pengembangan adalah modul 2 .

Tahap pengujian terdiri dari beberapa langkah yaitu: 1) uji coba terbatas, 2) revisi produk tahap II, 3) produk akhir. Uji coba terbatas dilaksanakan terhadap tiga guru matematika dan 20 siswa kelas VII MTs Negeri Ngawi. Dari hasil uji coba terbatas dan pengamatan dijadikan bahan evaluasi untuk revisi produk tahap II. Hasil dari tahap pengujian produk adalah produk akhir berupa modul matematika berilustrasi komik.

Berdasarkan hasil pengembangan yang sudah dilaksanakan diperoleh modul matematika berilustrasi komik yang valid/layak digunakan dalam kegiatan pembelajaran. Terbukti dengan skor hasil penilaian ahli materi rata-rata sebesar $84,90 \%$ dengan kategori 
"sangat baik", skor hasil penilaian ahli media rata-rata sebesar $81,11 \%$ dengan kategori "baik", dan skor hasil penilaian responden rata-rata sebesar 86,23\% dengan kategori "sangat baik". Modul matematika berilustrasi komik dikatakan layak karena mendapat penilaian "baik" dari reviewer. Hal ini sesuai dengan pendapat Beard dan Rhodes (2002) bahwa penggunaan komik dalam proses pembelajaran dapat merangsang motivasi dan ketertarikan siswa terhadap suatu pokok bahasan yang dianggap sulit untuk dimengerti, merangsang aktivitas diskusi, membangun pemahaman, dan memperpanjang daya ingat.

Uji efektivitas modul dilakukan dengan membandingkan prestasi belajar siswa pada kelas eksperimen dan kelas kontrol. Berikut ini adalah Tabel 1 berisi rangkuman data prestasi belajar siswa pada kelas eksperimen dan kelas kontrol.

Tabel 1. Deskripsi Data Prestasi Belajar Matematika Siswa

\begin{tabular}{llllll}
\hline Kelas Pembelajaran & N & Rata-Rata & Nilai Maks & Nilai Min & Standar Deviasi \\
\hline Kelas Eksperimen & 41 & 86,2439 & 100 & 64 & 8,9016 \\
Kelas Kontrol & 39 & 78,8718 & 96 & 56 & 11,6420 \\
\hline
\end{tabular}

Sebelum dilakukan uji hipotesis perlu dilakukan uji prasyarat terlebih dahulu yang meliputi uji normalitas dan uji homogenitas. Uji normalitas pada penelitian ini menggunakan metode Lilliefors. Sedangkan uji homogenitas pada penelitian ini menggunakan metode Bartlett. Hasil uji prasyarat menyimpulkan bahwa semua sampel berasal dari populasi yang berdistribusi normal dan mempunyai variansi yang sama. Uji keseimbangan dilakukan terhadap data kemampuan awal dengan tujuan untuk mengetahui apakah populasi siswa pada kelas eksperimen dan kelas kontrol dalam keadaan seimbang.

Berdasarkan uji hipotesis efektivitas modul pada kelas eksperimen dan kelas kontrol, diperoleh nilai $t_{\text {hitung }}$ sebesar 3,1922 dengan $t_{\text {tabel }}$ sebesar 1,1590, DK = $\{t \mid t>1,1590\}$ dan $t_{\text {hitung }} \in D K$ yang artinya $H_{0}$ ditolak. Jadi, dapat disimpulkan bahwa efektivitas modul baru lebih baik daripada modul lama. Hal ini berarti pembelajaran dengan menggunakan modul matematika berilustrasi komik memberikan efektivitas yang lebih baik daripada pembelajaran langsung yang tidak menggunakan modul matematika berilustrasi komik.

Selanjutnya, dengan melihat Tabel 1 rerata prestasi belajar siswa pada kelas eksperimen lebih besar daripada kelas kontrol. Pembelajaran dengan menggunakan modul matematika berilustrasi komik sebagai kelas eksperimen dengan rata-rata sebesar 86,24 lebih baik daripada pembelajaran yang tidak menggunakan modul matematika berilustrasi komik sebagai kelas kontrol dengan rata-rata sebesar 78,87.

Dengan demikian, kesimpulan ini sesuai dengan hipotesis yang diajukan yaitu pembelajaran dengan modul matematika berilustrasi komik pada materi skala dan 
perbandingan kelas VII SMP/MTs lebih efektif daripada pembelajaran langsung yang tidak menggunakan modul matematika berilustrasi komik dilihat dari prestasi belajar.

Pembelajaran dengan menggunakan modul matematika berilustrasi komik lebih memotivasi siswa untuk belajar mandiri. Hal ini sesuai dengan pendapat Mardiningsih (2009) bahwa penggunaan media komik apabila disajikan dengan baik akan merangsang minat dan perhatian siswa, karena sifatnya yang dapat membuat rasa senang. Selain itu. Menurut Joseph Le Doux ilmuwan saraf terkemuka (De Porter, 2000:23) bahwa komik merupakan media alternatif yang tepat untuk pembelajaran, karena keterlibatan emosi pembacanya akan sangat mempengaruhi memori dan daya ingat akan materi pelajaran yang didapat.

\section{SIMPULAN DAN SARAN}

Berdasarkan analisis data dan pembahasan dari penelitian dan pengembangan ini dapat disimpulkan bahwa. 1) Modul matematika berilustrasi komik layak digunakan dalam kegiatan pembelajaran. Terbukti dengan skor hasil penilaian ahli materi rata-rata sebesar $84,90 \%$ dengan kategori "sangat baik", skor hasil penilaian ahli media rata-rata sebesar $81,11 \%$ dengan kategori "baik", dan skor hasil penilaian responden rata-rata sebesar 86,23\% dengan kategori "sangat baik". Modul matematika berilustrasi komik dikatakan layak karena mendapat penilaian "baik" dari reviewer. 2) Rerata prestasi belajar siswa pada kelas eksperimen lebih besar daripada kelas kontrol. Pembelajaran dengan menggunakan modul matematika berilustrasi komik pada kelas eksperimen dengan rata-rata nilai sebesar 86,24 lebih baik daripada pembelajaran yang tidak menggunakan modul matematika berilustrasi komik pada kelas kontrol dengan rata-rata nilai sebesar 78,87. Kesimpulan ini sesuai dengan hipotesis yang diajukan yaitu pembelajaran dengan modul matematika berilustrasi komik pada materi skala dan perbandingan kelas VII SMP/MTs lebih efektif daripada pembelajaran langsung yang tidak menggunakan modul matematika berilustrasi komik dilihat dari prestasi belajar.

Berdasarkan hasil pembahasan dan kesimpulan yang diperoleh, maka penelitian ini memberikan implikasi sebagai berikut. 1) Implikasi teoritis: pembelajaran dengan menggunakan modul matematika berilustrasi komik dapat diterapkan pada materi skala dan perbandingan kelas VII SMP/MTs, pembelajaran dengan menggunakan modul matematika berilustrasi komik efektif untuk meningkatkan prestasi belajar siswa. 2) Implikasi praktis: modul matematika berilustrasi komik dapat dijadikan alternatif dalam pengembangan bahan ajar selanjutnya, pengembangan modul pembelajaran perlu menjadi perhatian khusus bagi para guru agar proses pembelajaran tidak membosankan dan siswa mendapatkan pengalaman belajar lain sehingga prestasi belajar menjadi lebih baik lagi. 
Berdasarkan kesimpulan dan implikasi dari penelitian dan pengembangan maka penulis bisa memberikan saran sebagai berikut. 1) Saran bagi guru; modul matematika berilustrasi komik ini dapat digunakan untuk materi skala dan perbandingan dan dijadikan salah satu contoh pengembangan modul pembelajaran bagi guru karena telah mengimplementasikan Kurikulum 2013, modul matematika berilustari komik dapat dijadikan sebagai rujukan dalam mengembangkan modul pembelajaran bagi guru sehingga guru akan lebih termotivasi dan kreatif dalam mengembangkan modul pembelajaran, modul matematika berilustrasi komik dapat dikembangkan untuk materi lain yang sesuai. 2) Saran bagi siswa: setiap siswa mempunyai motivasi belajar yang berbeda yang dapat dikembangkan, sebaiknya siswa memahami tujuan yang hendak dicapai pada setiap proses pembelajaran. 3) Saran bagi peneliti lain: hasil dari penelitian dan pengembangan dapat dijadikan sebagai acuan bagi peneliti selanjutnya yang sejenis dengan materi yang berbeda, penelitian ini hanya terbatas pada siswa kelas VII MTs Negeri Ngawi, sehingga perlu dilakukan penelitian di sekolah lain agar mendapatkan hasil yang lebih bervariasi.

\section{DAFTAR PUSTAKA}

Beard, C. and Rhodes, T. 2002. Experiential Learning: Using Comic Strips as'Reflective Tools' in Adult Learning. Australian Journal of Outdoor Education, vol. 6, no. 1, pp. 19-27.

Depdiknas. 2008. Teknik Penyusunan Modul. Jakarta: BSNP.

De Porter, B. 2000. Quantum Teaching. Bandung: Kaifa.

Ginting, V. 2005. Penguatan Membaca, Fasilitas Lingkungan Sekolah, dan Keterampilan Dasar Membaca Bahasa Indonesia serta Minat Baca Murid. Jurnal Pendidikan Penabur, vol. 4, no. 4, hlm. 17 - 34 .

Kurniawati, I. 2013. Pengembangan Bahan Ajar, (Online). (www.kemendikbud.go.id).

Mardiningsih, D. 2009. Efektivitas Media Cetak Dalam Usaha Meningkatkan Pengetahuan Peternak Ayam Buras Tentang Flu Burung. Seminar Nasional Kebangkitan Peternakan. Fakultas Peternakan Universitas Diponegoro. Semarang.

Novianti, R. D. dan Syaichudin, M. 2010. Pengembangan Media Komik Pembelajaran Matematika untuk Meningkatkan Pemahaman Bentuk Soal Cerita Bab Pecahan pada Siswa Kelas V SDN Ngembung. Jurnal Teknologi Pendidikan, vol. 10, no. 1, hlm. 74-85.

Sadiman. 2012. Media Pendidikan. Jakarta: Raja Grafindo Persada.

Sukmadinata. 2013. Metode Penelitian Pendidikan. Bandung: PT Remaja Rosda Karya. 
Sungkono. 2009. Pengembangan dan Pemanfaatan Bahan Ajar Modul dalam Proses Pembelajaran, (Online). (http://uny.ac.id).

Tatalovic, M. 2009. Visual Literacy to Comics or Not Comics. World Library and Information Congress $75^{\text {th }}$ IFLA General Conference and Council. Midrand Graduate Institute.

Zakaria, E., Chin, L.C., and Daud, M.Md., 2010. The Effects of Cooperative Learning on Students Mathematics Achievement and Attitude towards Mathematics. Journal of Social Sciences, vol. 6, no. 2, pp. 272-275. 